\title{
RESEARCH
}

Open Access

\section{Second-generation pterocarpanquinones: synthesis and antileishmanial activity}

Viviane dos Santos Faiões' ${ }^{1}$ Lívia C. R. M. da Frota², Edézio Ferreira Cunha-Junior' ${ }^{1}$, Julio C. F. Barcellos², Thayssa Da Silva ${ }^{3}$, Chaquip Daher Netto ${ }^{4}$, Silvia Amaral Gonçalves Da-Silva ${ }^{3}$, Alcides J. M. da Silva²,

Paulo R. R. Costa ${ }^{2}$ and Eduardo Caio Torres-Santos ${ }^{1 *}$ (D)

\begin{abstract}
Background: Despite the development of new therapies for leishmaniasis, among the 200 countries or territories reporting to the $\mathrm{WHO}, 87$ were identified as endemic for Tegumentary Leishmaniasis and 75 as endemic for Visceral Leishmaniasis. The identification of antileishmanial drug candidates is essential to fill the drug discovery pipeline for leishmaniasis. In the hit molecule LQB-118 selected, the first generation of pterocarpanquinones was effective and safe against experimental visceral and cutaneous leishmaniasis via oral delivery. In this paper, we report the synthesis and antileishmanial activity of the second generation of pterocarpanoquinones.

Methods: The second generation of pterocarpanquinones 2a-f was prepared through a palladium-catalyzed oxyarylation of dihydronaphtalen and chromens with iodolawsone, easily prepared by iodination of lawsone. The spectrum of antileishmanial activity was evaluated in promastigotes and intracellular amastigotes of L. amazonensis, L. braziliensis, and L. infantum. Toxicity was assessed in peritoneal macrophages and selective index calculated by $C C_{50} / C_{50}$. Oxidative stress was measured by intracellular ROS levels and mitochondrial membrane potential in treated cells.

Results: In this work, we answered two pertinent questions about the structure of the first-generation pterocarpanquinones: the configuration and positions of rings B (pyran) and C (furan) and the presence of oxygen in the $B$ ring. When rings $B$ and $C$ are exchanged, we noted an improvement of the activity against promastigotes and amastigotes of $L$. amazonensis and promastigotes of $L$. infantum. As to the oxygen in ring $B$ of the new generation, we observed that the oxygenated compound $2 \mathrm{~b}$ is approximately twice as active against $L$. braziliensis promastigotes than its deoxy derivative 2a. Another modification that improved the activity was the addition of the methylenedioxy group. A variation in the susceptibility among species was evident in the clinically relevant form of the parasite, the intracellular amastigote. L. amazonensis was the species most susceptible to novel derivatives, whilst $L$. infantum was resistant to most of them. The pterocarpanoquinones ( $2 \mathrm{~b}$ and $2 \mathrm{c}$ ) that possess the oxygen atom in ring B showed induction of increased ROS production.
\end{abstract}

Conclusions: The data presented indicate that the pterocarpanoquinones are promising compounds for the development of new leishmanicidal agents.

Keywords: Leishmania, Pterocarpanquinone, LQ-118, Phenotypic assay, Leishmaniasis, Drug discovery, Neglected diseases

\footnotetext{
* Correspondence: ects@ioc.fiocruz.br

'Laboratório de Bioquímica de Tripanosomatídeos, Instituto Oswaldo Cruz, FIOCUZ, Av. Brasil, 4365, Pavilhao Leonidas Deane, sala 405A, Manguinhos, Rio de Janeiro, RJ 21040-900, Brazil

Full list of author information is available at the end of the article
}

(c) The Author(s). 2018 Open Access This article is distributed under the terms of the Creative Commons Attribution 4.0 International License (http://creativecommons.org/licenses/by/4.0/), which permits unrestricted use, distribution, and reproduction in any medium, provided you give appropriate credit to the original author(s) and the source, provide a link to the Creative Commons license, and indicate if changes were made. The Creative Commons Public Domain Dedication waiver (http://creativecommons.org/publicdomain/zero/1.0/) applies to the data made available in this article, unless otherwise stated. 


\section{Background}

The first generation of pterocarpanquinones was designed for the new chemical entity (NCE) based on the molecular hybridization of two pharmacophores, quinone, and pterocarpan (derivatives of isoflavonoids) (Fig. 1). Natural quinones represent one of the major classes of natural products with significant biological activity against parasites of the genera Leishmania, Trypanosoma, and Plasmodium. Pterocarpan derivatives, such as maackiain and others, have frequently shown antiprotozoal activity [1]. Two distinct pharmacophoric sites were combined in order to amplify the action spectrum of these groups. This series of derivatives were synthesized through a palladium-catalyzed oxyarylation reaction and screened for their biological activities. Different studies of the group showed a relevant antiparasitic and anti-cancer activity [2-4]. The hit molecule selected LQB-118 (1) (Fig. 1) showed antineoplasic activity against cultured breast cancer, leukemia, lung cancer cell lines and prostate cancer cell [5-10], some of which present a Multidrug Resistance phenotype [11]. This hit showed low toxicity for PBMC human blood cells and cell line macrophages, evidencing a high selectivity index [3]. We have also demonstrated that LQB-118 is effective in treating experimental visceral (Leishmania infantum) and cutaneous (L. amazonensis and L. braziliensis) leishmaniasis via oral delivery, and therapeutic safety in a repeated toxicity study [12-14]. The death of $L$. amazonensis parasites involved oxidative stress with the hallmarks of apoptosis, similar to cancer-induced death [15]. Despite the development of new therapies for leishmaniasis, in 2015, among the 200 countries or territories reporting to World Health Organization, 87 were identified as endemic for TegumentaryLeishmaniasis (CL) while 75 were considered endemic for Visceral Leishmaniasis (VL) [16]. The clinical forms of the disease, i.e., cutaneous, diffuse, disseminated, mucocutaneous and visceral, are a result of the conjunction of parasite species and the immunological response of patients [17]. It is considered the third most common parasitic disease after schistosomiasis and malaria, based on morbidity and disability-adjusted life years (DALYs) [18]. Besides the fact that the medications (pentavalent antimonials, pentamidine, amphotericin B, liposomal amphotericin B, miltefosine, and paromomycin) are not approved in all countries, leishmaniasis faces the challenge of old and new toxicity concerns with current therapeutic regimens and parasite resistance. If we consider the number of pathogenic species in relation to therapeutic options, this arsenal is still small. Thus, the identification of antileishmanial drug candidates is essential to fill the drug discovery pipeline for leishmaniasis [19]. The biological potential of LQB-118 prompted us to synthesize the second generation of pterocarpanoquinones, which was based on the exchange of position between rings B (pyran) and $C$ (furan), yielding six derivatives $2 a-f$ as shown in Fig. 1, to further investigate the structural features required for the antileishmanial activity. In this paper we report the synthesis of these compounds, the antileishmanial activity on promastigotes and intracellular amastigotes of three species of Leishmania (L. amazonensis, $L$. braziliensis and L. infantum); the selective index was evaluated in murine macrophages and the potential for inducing oxidative stress and alterations in the mitochondrial membrane potential $(\Delta \psi \mathrm{m})$ in the parasite.

\section{Methods}

\section{Chemistry}

Pterocarpanquinones 2a-f were prepared through a palladium-catalyzed oxyarylation of dihydronaphtalen (3a, e, and f) and chromens 3b-d with 3-iodolawsone (4), easily prepared by iodination of lawsone [4, 20-22].

Melting points were determined by a Thomas-Hoover apparatus. Column chromatography was performed on

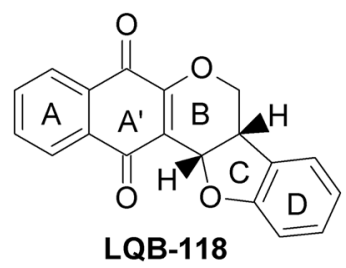

(1)

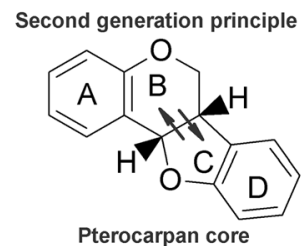

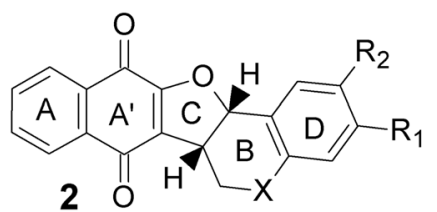

$\|$

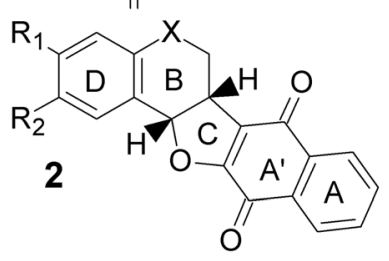

For 2

a: $X=\mathrm{CH}_{2}, \mathrm{R}_{1}=\mathrm{R} 2=\mathrm{H}$;

b: $X=\mathrm{O}, \mathrm{R}^{1}=\mathrm{R} 2=\mathrm{H}$;

c: $X=O, R^{1}=H, R_{2}=C l$;

d: $\mathrm{X}=\mathrm{O}, \mathrm{R} 1=\mathrm{R}^{2}=\mathrm{OCH} 2 \mathrm{O}$;

e: $\mathrm{X}=\mathrm{CH}^{2}, \mathrm{R}^{1}=\mathrm{OCH}^{3}, \mathrm{R}^{2}=\mathrm{H}$;

f: $X=\mathrm{CH}_{2}, \mathrm{R}_{1}=\mathrm{H}, \mathrm{R}_{2}=\mathrm{OCH}^{3}$

Fig. 1 Planning of second generation pterocarpanoquinones. Design of pterocarpanquinones was based on molecular hybridization of quinone and pterocarpan core. LQB-118 (1) and second generation (2a-f) 
silica gel 230-400 mesh (Aldrich). The ${ }^{1} \mathrm{H}$ NMR spectrum was recorded on a Varian $(400$ or $500 \mathrm{MHz})$ spectrometer at room temperature. All J values are given in $\mathrm{Hz}$. Chemical shifts are expressed as parts per million downfield shift from tetramethylsilane as an internal standard, and reported as position $(\delta \mathrm{H})$ (relative integral, multiplicity $(\mathrm{s}=$ singlet, $\mathrm{d}=$ doublet, $\mathrm{dd}=$ double doublet, $\mathrm{dt}=$ double triplet, $\mathrm{m}=$ multiplet $)$, coupling constant $(\mathrm{J}$ $\mathrm{Hz}$ ) and assignment. The 13C NMR spectrum was recorded on a Varian $(100 \mathrm{MHz})$ spectrometer at room temperature with complete proton decoupling. Data are expressed as parts per million ownfield shift from tetramethylsilane as an internal standard and reported as position $(\delta C)$.

General procedure for the oxyarylation: Synthesis of compounds type 2 . To a stirred solution of 3 (0.33 $\mathrm{mmol})$ and $4(0.66 \mathrm{mmol})$ or $5(0.66 \mathrm{mmol})$ in acetone $(2 \mathrm{~mL})$ or pinacolone $(2 \mathrm{~mL})$, silver carbonate $(0.5$ $\mathrm{mmol})$ and $\mathrm{Pd}(\mathrm{OAc})_{2}(10 \mathrm{~mol} \%)$ were added. The reaction mixture was refluxed for $18 \mathrm{~h}$ or irradiated for $40 \mathrm{~min}$ and filtered in celite with ethyl acetate. The organic layer was washed with brine, dried over anhydrous $\mathrm{Na}_{2} \mathrm{SO}_{4}$ and concentrated. The crude product was washed in $\mathrm{n}$-hexane and purified by flash chromatography on silica.

General procedure for oxyarilations in PEG-400 for syntheses of 2a-f compounds: To $90 \mathrm{mg}(0.3 \mathrm{mmol})$ of 3 , $4.6 \mathrm{mg}(0.02 \mathrm{mmol})$ of $\mathrm{Pd}(\mathrm{OAc})_{2}$ and $60.7 \mathrm{mg}(0.22$ $\mathrm{mmol}$ ) of $\mathrm{Ag}_{2} \mathrm{CO}_{3}$ in $0.4 \mathrm{~mL}$ of PEG-400, $0.2 \mathrm{mmol}$ of dihydronaphtalene or chromene was added. After 10 min at $140{ }^{\circ} \mathrm{C}$, TLC analysis showed that all starting materials were consumed. Then, the mixture was filtered in filter paper and transferred to a separation funnel with ethylacetate $(20 \mathrm{~mL})$ and washed with brine. $(2 \mathrm{X} 40 \mathrm{~mL})$. After evaporation in the vacuum, the evaporated residue was percolated in silica flash pad using $20 \%$ ethyl acetate in hexane as eluent giving the adducts in yields described in Tables 1 and 3.

Table 1 Yields and major conditions for reactions shown in Scheme 1

\begin{tabular}{llll}
\hline Entry & Heat & Cond. $^{\text {a }}$ & 2 (\%) \\
\hline 1 & $\Delta$ & A & 2a (20\%) \\
2 & MW $^{\mathrm{b}}$ & $\mathrm{A}$ & $2 \mathrm{a}(31 \%)$ \\
3 & $\Delta$ & $\mathrm{B}$ & $2 \mathrm{a}(57 \%)$ \\
4 & $\mathrm{MW}^{\mathrm{b}}$ & $\mathrm{B}$ & $2 \mathrm{a}(50 \%)$ \\
5 & $\Delta$ & $\mathrm{C}$ & $2 \mathrm{a}(65 \%)$ \\
6 & $\Delta$ & $\mathrm{D}$ & $2 \mathrm{e}(47 \%)$ \\
7 & $\Delta$ & $\mathrm{D}$ & $2 \mathrm{e}(46 \%)$
\end{tabular}

${ }^{a}$ Conditions: $\mathrm{A}-\mathrm{Pd}(\mathrm{OAc})_{2}(10 \mathrm{~mol} \%), \mathrm{Ag}_{2} \mathrm{CO}_{3}$ (1.5 equiv.), acetone, reflux, $18 \mathrm{~h}$; $\mathrm{B}-\mathrm{Pd}(\mathrm{OAc})_{2}(10 \mathrm{~mol} \%), \mathrm{Ag}_{2} \mathrm{CO}_{3}$ (1.5 equiv.), pinacolone, reflux, $18 \mathrm{~h}$; C $\mathrm{Pd}(\mathrm{OAc})_{2}(10 \mathrm{~mol} \%), \mathrm{Ag}_{2} \mathrm{CO}_{3}$ (1.1 equiv.), $\mathrm{PEG}-400,140^{\circ} \mathrm{C}, 10 \mathrm{~min}$.; $\mathrm{D}-\mathrm{Pd}(\mathrm{OAc})_{2}$ (10 mol\%), $\mathrm{Ag}_{2} \mathrm{CO}_{3}$ (1.1 equiv.), PEG-400, $90^{\circ} \mathrm{C}, 10 \mathrm{~min}$

${ }^{b} \mathrm{MW}$ : $40 \mathrm{~W}, 60^{\circ} \mathrm{C}$ (acetone) or $110^{\circ} \mathrm{C}$ (pinacolone), $40 \mathrm{~min}$

\section{Compound 2a}

After column chromatography using n-hexane/ethyl acetate (98:2) as eluant, this compound was obtained as a yellow solid in $57 \%$ yield in pinacolone under reflux, mp / at $200{ }^{\circ} \mathrm{C} .1 \mathrm{H} \mathrm{NMR} \mathrm{(CDCl3)} \delta(\mathrm{ppm}) 8.09$ (ddd, J = 9.2 Hz, $7.5 \mathrm{~Hz}, 1.4 \mathrm{~Hz}, 2 \mathrm{H}) ; 7.73(\mathrm{td}, \mathrm{J}=7.5$ $\mathrm{Hz}, 1.4 \mathrm{~Hz}, 1 \mathrm{H}) ; 7.68(\mathrm{td}, \mathrm{J}=7.5 \mathrm{~Hz}, 1.4 \mathrm{~Hz}, 1 \mathrm{H})$; 7.61-7.55 (m, $1 \mathrm{H}) ; 7.33-7.28(\mathrm{~m}, 2 \mathrm{H}) ; 7.20-7.16(\mathrm{~m}$, $1 \mathrm{H}) ; 5.92(\mathrm{~d}, \mathrm{~J}=9.8 \mathrm{~Hz}, 1 \mathrm{H}) ; 3.93(\mathrm{ddd}, \mathrm{J}=9.8 \mathrm{~Hz}, 7.1$ $\mathrm{Hz}, 6.0 \mathrm{~Hz}, 1 \mathrm{H}) ; 2.77(\mathrm{ddd}, \mathrm{J}=15.6 \mathrm{~Hz}, 8.4 \mathrm{~Hz}, 3.8 \mathrm{~Hz}$, $1 \mathrm{H}) ; 2.66$ (ddd, $J=15.6 \mathrm{~Hz}, 8.4 \mathrm{~Hz}, 3.8 \mathrm{~Hz}, 1 \mathrm{H}$ ); $2.24-$ $2.13(\mathrm{~m}, 1 \mathrm{H}) ; 2.08-1.96(\mathrm{~m}, 1 \mathrm{H}) ; 13 \mathrm{C} \mathrm{NMR}(\mathrm{CDCl} 3$, $100 \mathrm{MHz}) \delta(\mathrm{ppm})$ 182.4 (C); 177.9 (C); 160.2 (C); $139.3(\mathrm{C}) ; 134.1(\mathrm{CH}) ; 133.2(\mathrm{CH}) ; 132.9(\mathrm{C}) ; 131.5$ (C); $130.9(\mathrm{CH}) ; 130.5(\mathrm{CH}) ; 129.0(\mathrm{CH}) ; 128.4(\mathrm{CH})$; 126.9 (C); $126.6(\mathrm{CH}) ; 126.3(\mathrm{C}) ; 125.9(\mathrm{CH}) ; 84.9$ $(\mathrm{CH}) ; 39.9(\mathrm{CH}) ; 27.2(\mathrm{CH} 2) ; 25.5(\mathrm{CH} 2) ; \mathrm{MS}: \mathrm{m} / \mathrm{z}$ 302 (100\%), m/z 130 (74\%).

\section{Compound $2 \mathrm{~b}$}

After column chromatography using n-hexane/ethyl acetate (98:2) as eluant, this compound was obtained as a yellow solid in $30 \%$ yield in pinacolone under microwave irradiation, $\mathrm{mp} /$ at $190^{\circ} \mathrm{C} .1 \mathrm{H}$ NMR $(\mathrm{CDCl} 3,400$ $\mathrm{MHz}) \delta(\mathrm{ppm}) 8.12-8.06(\mathrm{~m}, 2 \mathrm{H}) ; 7.75(\mathrm{td}, \mathrm{J}=7.5 \mathrm{~Hz}$, $1.3 \mathrm{~Hz}, 1 \mathrm{H}) ; 7.69(\mathrm{td}, \mathrm{J}=7.5 \mathrm{~Hz}, 1.3 \mathrm{~Hz}, 1 \mathrm{H}) ; 7.56(\mathrm{dd}, \mathrm{J}$ $=7.6 \mathrm{~Hz}, 1.3 \mathrm{~Hz}, 1 \mathrm{H}) ; 7.34-7.27(\mathrm{~m}, 1 \mathrm{H}) ; 7.07(\mathrm{t}, \mathrm{J}=7.6$ $\mathrm{Hz}, 1 \mathrm{H}) ; 6.95(\mathrm{~d}, \mathrm{~J}=8.2 \mathrm{~Hz}, 1 \mathrm{H}) ; 5.90(\mathrm{~d}, \mathrm{~J}=9.3 \mathrm{~Hz}, 1 \mathrm{H})$; $4.43(\mathrm{dd}, \mathrm{J}=11.2 \mathrm{~Hz}, 4.8 \mathrm{~Hz}, 1 \mathrm{H}) ; 4.18(\mathrm{dd}, \mathrm{J}=11.2 \mathrm{~Hz}$, $7.6 \mathrm{~Hz}, 1 \mathrm{H}) ; 4.02($ ddd, $\mathrm{J}=9.3 \mathrm{~Hz}, 7.6 \mathrm{~Hz}, 4.8 \mathrm{~Hz}, 1 \mathrm{H})$; 13C NMR (CDCl3, $100 \mathrm{MHz}) \delta(\mathrm{ppm}) 182.1(\mathrm{C}) ; 177.6$ (C); 160.8 (C); $156.2(\mathrm{C}) ; 134.3(\mathrm{CH}) ; 133.1(\mathrm{CH}) ; 132.9$ (C); $131.5(\mathrm{C}) ; 131.1(\mathrm{CH}) ; 130.8(\mathrm{CH}) ; 126.4(\mathrm{CH})$; $126.0(\mathrm{C}) ; 123.4(\mathrm{CH}) ; 122.3(\mathrm{CH}) ; 118.8(\mathrm{C}) ; 117.8$ $(\mathrm{CH}) ; 80.7(\mathrm{CH}) ; 65.3(\mathrm{CH} 2) ; 40.2(\mathrm{CH}) ; \mathrm{MS}: \mathrm{m} / \mathrm{z} 304$ (26\%), 131 (100\%).

\section{Compound $2 \mathrm{c}$}

After column chromatography using n-hexane/ethyl acetate (98:2) as eluant, this compound was obtained as a yellow solid in $25 \%$ yield in pinacolone under reflux, mp / at $220^{\circ} \mathrm{C} .1 \mathrm{H} \mathrm{NMR} \mathrm{(400} \mathrm{MHz,} \mathrm{acetone)} \delta$ 8.09-8.01 (m, J = 14.0, 7.6 Hz, $2 \mathrm{H}), 7.90-7.78(\mathrm{~m}, 2 \mathrm{H})$, $7.60(\mathrm{~d}, \mathrm{~J}=2.6 \mathrm{~Hz}, 1 \mathrm{H}), 7.34(\mathrm{dd}, \mathrm{J}=8.8,2.6 \mathrm{~Hz}, 1 \mathrm{H})$, $6.97(\mathrm{~d}, \mathrm{~J}=8.8 \mathrm{~Hz}, 1 \mathrm{H}), 6.05(\mathrm{~d}, \mathrm{~J}=9.5 \mathrm{~Hz}, 1 \mathrm{H}), 4.41$ $(\mathrm{dd}, \mathrm{J}=11.4,4.7 \mathrm{~Hz}, 1 \mathrm{H}), 4.31(\mathrm{dd}, \mathrm{J}=11.4,6.9 \mathrm{~Hz}$, $1 \mathrm{H}), 4.16(\mathrm{ddd}, \mathrm{J}=9.5,6.9,4.7 \mathrm{~Hz}, 1 \mathrm{H}) ; 13 \mathrm{C}$ NMR (101 MHz, acetone) $\delta 181.7(\mathrm{C}), 177.1(\mathrm{C}), 160.5(\mathrm{C})$, $155.2(\mathrm{C}), 134.2(\mathrm{CH}), 133.2(\mathrm{CH}), 133.0(\mathrm{C}), 131.7$ (C), $130.5(\mathrm{CH}), 126.1(\mathrm{C}), 125.8(\mathrm{CH}), 125.5(\mathrm{CH})$, $123.2(\mathrm{C}), 121.7(\mathrm{CH}), 119.4(\mathrm{C}), 119.3(\mathrm{CH}), 79.6$ (CH), $65.2(\mathrm{CH} 2), 40.0(\mathrm{CH}) ; \mathrm{MS}: \mathrm{m} / \mathrm{z} 340$ (15\%), 338 (45\%), m/z 168 (33\%), 166 (100\%). 


\section{Compound 2d}

After column chromatography using n-hexane/ethyl acetate (98:2) as eluant, this compound was obtained as a light brown solid in $25 \%$ yield in acetone under reflux, $\mathrm{mp} /$ at $162{ }^{\circ} \mathrm{C} .1 \mathrm{H} \mathrm{NMR}(400 \mathrm{MHz}, \mathrm{cdcl} 3) \delta 8,09$ (dd, J $=5,7 \mathrm{~Hz}, 2,3 \mathrm{~Hz}, 2 \mathrm{H}), 7,78-7,66(\mathrm{~m}, 2 \mathrm{H}) ; 6,94(\mathrm{~s}, 1 \mathrm{H})$; $6,46(\mathrm{~s}, 1 \mathrm{H}) ; 5,95(\mathrm{~d}, \mathrm{~J}=0,9 \mathrm{~Hz}, 1 \mathrm{H}) ; 5,93(\mathrm{~d}, \mathrm{~J}=0,9 \mathrm{~Hz}$, $1 \mathrm{H}), 5,82(\mathrm{~d}, \mathrm{~J}=9,3 \mathrm{~Hz}, 1 \mathrm{H}) ; 4,36(\mathrm{dd}, \mathrm{J}=10.9 \mathrm{~Hz}, 4,8 \mathrm{~Hz}$, $1 \mathrm{H}) ; 4,13(\mathrm{dd}, \mathrm{J}=10,9 \mathrm{~Hz}, 7,5 \mathrm{~Hz}, 1 \mathrm{H}) ; 3,95$ (ddd, $\mathrm{J}=9,3$ $\mathrm{Hz}, 7,5 \mathrm{~Hz}, 4,8 \mathrm{~Hz}, 1 \mathrm{H}) ; 13 \mathrm{C}$ NMR $(101 \mathrm{MHz}$, acetone) $\delta$ 181.7 (C), 177.2 (C), 160.7 (C), 152.1 (C), 149.3 (C), $142.8(\mathrm{C}), \quad 134.2(\mathrm{CH}), 133.1(\mathrm{CH}), 131.7(\mathrm{C}), 125.8$ $(\mathrm{CH}), 125.5(\mathrm{CH}), 123.3(\mathrm{C}), 111.5(\mathrm{CH}), 108.8(\mathrm{C})$, $101.6(\mathrm{CH} 2), 98.7(\mathrm{C}), 81.1(\mathrm{CH}), 65.3(\mathrm{CH} 2), 54.0(\mathrm{CH})$, $39.8(\mathrm{CH})$.

\section{Compound 2e}

After column chromatography using n-hexane/ethyl acetate (95:5) as eluant, this compound was obtained as a yellow solid in $47 \%$ yield in PEG-400 under heating at $90{ }^{\circ} \mathrm{C} .1 \mathrm{H} \mathrm{NMR}(400 \mathrm{MHz}, \mathrm{CDCl} 3): \delta=8.08(\mathrm{t}, \mathrm{J}=7.7$ $\mathrm{Hz}, 2 \mathrm{H}), 7.76-7.71(\mathrm{~m}, 1 \mathrm{H}), 7.70-7.64(\mathrm{~m}, 1 \mathrm{H}), 7.48$ $(\mathrm{d}, \mathrm{J}=8.5 \mathrm{~Hz}, 1 \mathrm{H}), 6.84(\mathrm{dd}, \mathrm{J}=8.4,2.5 \mathrm{~Hz}, 1 \mathrm{H}), 6.70$ $(\mathrm{d}, \mathrm{J}=2.2 \mathrm{~Hz}, 1 \mathrm{H}), 5.91(\mathrm{~d}, \mathrm{~J}=9.7 \mathrm{~Hz}, 1 \mathrm{H}), 3.91(\mathrm{dt}, \mathrm{J}=$ 9.7, $6.3 \mathrm{~Hz}, 1 \mathrm{H}), 3.81(\mathrm{~s}, 3 \mathrm{H}), 2.80-2.68(\mathrm{~m}, 1 \mathrm{H}), 2.63$ (ddd, J = 11.9, 7.0, 4.3 Hz, $1 \mathrm{H}), 2.19-2.02(\mathrm{~m}, 2 \mathrm{H}) .13 \mathrm{C}$ NMR (101 MHz, CDCl3): $\delta=182.42,178.03,160.30$, $159.98,141.20,134.14,133.18,132.92,132.05,131.45$, $130.23,126.29,125.93,123.21,113.39,112.64,85.27$, 55.29, 39.72, 27.46, 25.49. HRMS: $\mathrm{m} / \mathrm{z}[\mathrm{M}+\mathrm{Na}]+$ calcd for C21H16O4Na: 355.0940; found: 355.0944.

\section{Compound $2 f$}

After column chromatography using n-hexane/ethyl acetate (95:5) as eluant, this compound was obtained as a yellow solid in $46 \%$ yield in PEG-400 under heating at $90^{\circ} \mathrm{C}$. $1 \mathrm{H}$ NMR $(400 \mathrm{MHz}, \mathrm{CDCl} 3): \delta=8.09$ (ddd, $\mathrm{J}=$ 7.2, 5.7, $1.3 \mathrm{~Hz}, 2 \mathrm{H}), 7.74(\mathrm{td}, \mathrm{J}=7.5,1.4 \mathrm{~Hz}, 1 \mathrm{H}), 7.68$ (td, J = 7.5, 1.4 Hz, $1 \mathrm{H}), 7.12(\mathrm{~d}, \mathrm{~J}=2.7 \mathrm{~Hz}, 1 \mathrm{H}), 7.09$ (d, $\mathrm{J}=8.4 \mathrm{~Hz}, 1 \mathrm{H}), 6.87(\mathrm{dd}, \mathrm{J}=8.4,2.7 \mathrm{~Hz}, 1 \mathrm{H}), 5.87(\mathrm{~d}, \mathrm{~J}$ $=9.7 \mathrm{~Hz}, 1 \mathrm{H}), 3.90(\mathrm{ddd}, \mathrm{J}=9.7,7.7,5.7 \mathrm{~Hz}, 1 \mathrm{H}), 3.84$ (s, $3 \mathrm{H}$ ), 2.71 (ddd, J = 15.5, 8.0, 3.8 Hz, $1 \mathrm{H}$ ), 2.65-2.56 (m, $1 \mathrm{H}), 2.25-2.14(\mathrm{~m}, 1 \mathrm{H}), 2.02-1.91(\mathrm{~m}, 1 \mathrm{H}) .13 \mathrm{C}$ NMR (101 MHz, CDCl3): $\delta=182.37,177.99,160.00$, $158.34,134.17,133.14,132.96,131.73,131.45,131.16$, $129.48,126.85,126.31,125.97,115.78,114.51,84.96$, 55.46, 39.83, 26.49, 25.71. HRMS: $\mathrm{m} / \mathrm{z}[\mathrm{M}+\mathrm{Na}]+$ calcd for C21H16O4Na: 355.0940; found: 355.0935.

\section{Ethics statement}

The studies were performed in accordance with protocols approved by the Ethics Committee for Animal Use of the Oswaldo Cruz Foundation (LW07/2010) under the protocol 044/2009, and approved by the Ethics
Committee on Animal Use (CEUA) of the Instituto de Biologia Roberto Alcantara Gomes of the Universidade do Estado do Rio de Janeiro-UERJ.

\section{Parasites}

Leishmania amazonensis (MHOM/BR/77/LTB0016) was maintained as promastigotes at $26^{\circ} \mathrm{C}$ in Schneider's insect medium (Sigma-Aldrich) supplemented with $10 \%$ heat-inactivated fetal calf serum (HIFCS), streptomycin at $100 \mu \mathrm{g} / \mathrm{mL}$ and penicillin at $100 \mathrm{U} / \mathrm{mL}$. New cultures of promastigotes were obtained from infected Balb/C mice.

L. braziliensis (MCAN/BR/98/R619) was routinely isolated from hamster lesions and maintained as promastigotes in Schneider's insect medium containing 20\% HIFCS and $100 \mu \mathrm{g} / \mathrm{ml}$ gentamicin (Schering-Plough). New cultures of promastigotes were obtained from an infected hamster.

Leishmania infantum (MHOM/MA67ITMAP263) parasites were isolated from female BALB/c mice infected and cultured at $26^{\circ} \mathrm{C}$ in Schneider's insect medium supplemented with $20 \%$ HIFCS, streptomycin at $100 \mu \mathrm{g} / \mathrm{ml}$ and penicillin at $100 \mathrm{U} / \mathrm{ml}$. New cultures of promastigotes were obtained from infected Balb/C mice.

\section{Antipromastigote test}

Leishmania promastigotes of three species were incubated in 96-well plates (Nunc, Roskilde, Denmark) under the conditions described above in either the absence or presence of different concentrations of pterocarpanquinones $2 \mathrm{a}-\mathrm{f}(0-100 \mu \mathrm{M})$. A stock solution of the compounds was prepared at $50 \mathrm{mM}$ in dimethylsulfoxide (Sigma Aldrich). The maximum solvent concentration used in the assays was $0.4 \%$ in a final volume per well of $200 \mu \mathrm{L}$. The cultures were initiated with $1.0 \times 10^{6}$ cells/ $\mathrm{ml}$ and maintained at $26^{\circ} \mathrm{C}$ for $72 \mathrm{~h}$. Inhibition of parasitic growth was determined by cell viability indicator, resazurin [23], with excitation $\lambda=560 \mathrm{~nm}$ and emission $\lambda=590 \mathrm{~nm}$ or the number of parasites was then counted in a Neubauer chamber (experiments with L. braziliensis). The $50 \%$ inhibitory concentration $\left(\mathrm{IC}_{50}\right)$ was determined by nonlinear regression analysis in the software GraphPad Prism 5.

\section{Antiamastigote test}

For the test against intracellular amastigotes of L. amazonensis and $L$. infantum, resident peritoneal macrophages (swiss mouse) were plated in RPMI (Sigma-Aldrich) at $2 \times 10^{6} / \mathrm{mL}(0.4 \mathrm{~mL} /$ well $)$ in Lab-Tek eight-chamber slides (Nunc, Roskilde, Denmark) and incubated at $37{ }^{\circ} \mathrm{C}$ in $5 \%$ $\mathrm{CO}_{2}$ for $1 \mathrm{~h}$. Stationary-phase L. amazonensis and $L$. infantum promastigotes were added at respective parasite/ macrophage ratios of 3:1 and 5:1 for $4 \mathrm{~h}$. After washing three times, pterocarpanquinones $2 \mathrm{a}-\mathrm{f}$ at various concentrations were added for $72 \mathrm{~h}$. Next, the slides were stained 


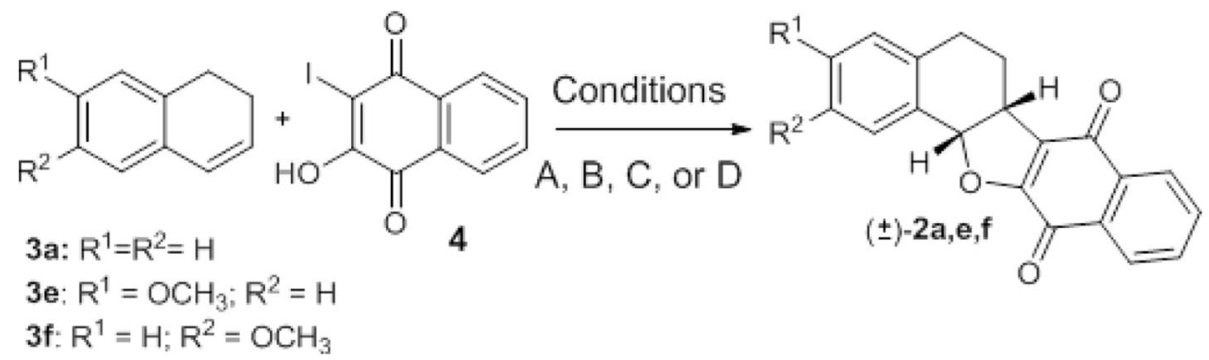

Scheme 1 Palladium-catalyzed oxyarylation of $3 a$, e, and $f$ with 4

using an Instant Prov hematological dye system (Newprov, Curitiba, Brazil). The number of amastigotes was determined by counting at least 100 macrophages per sample.

Macrophages of golden hamsters were used in assays against intracellular amastigotes of $L$. braziliensis due to the natural resistance of mice. Resident macrophages were obtained from the peritoneal cells of golden hamsters after a peritoneal injection of $10 \mathrm{~mL}$ of Dulbecco's Modified Eagle's medium (DMEM) (Sigma-Aldrich). The peritoneal macrophages were plated onto glass coverslips placed within the wells of a 24-well culture plate and incubated at $37^{\circ} \mathrm{C}$ in $5 \% \mathrm{CO}_{2}$ for $1 \mathrm{~h}$. After removing the nonadherent cells, the monolayers were infected with stationary-phase $L$. braziliensis promastigotes at a 5:1 parasite/macrophage ratio for $4 \mathrm{~h}$. The infected macrophages were washed and incubated with several pterocarpanquinone concentrations $(0-25 \mu \mathrm{M})$ for $72 \mathrm{~h}$. The monolayers were then stained with Giemsa, and at least 100 infected macrophages per sample were counted under optical microscopy.

The results were expressed as an infection index (\% infected cells $\times$ number of amastigotes/total number of macrophages). The $50 \%$ inhibitory concentration $\left(\mathrm{IC}_{50}\right)$ was determined by nonlinear regression analysis in the software GraphPad Prism 5.

\section{Macrophage toxicity test}

To evaluate the toxicity of pterocarpanquinones 2a-f, peritoneal macrophages of Swiss mice $\left(2 \times 10^{6} / \mathrm{mL}\right)$ were incubated with pterocarpanquinones $(1.25-100 \mu \mathrm{M})$ for $72 \mathrm{~h}$ at $37^{\circ} \mathrm{C} / 5 \% \mathrm{CO}_{2}$. Viability was evaluated with resazurin assay as described for the antipromastigote test.
The $50 \%$ cytotoxicity concentration $\left(\mathrm{CC}_{50}\right)$ was determined by nonlinear regression analysis in the software GraphPad Prism 5.

\section{Measurement of reactive oxygen species}

Intracellular ROS levels were measured in treated and untreated cells as described previously [15]. Briefly, $1 \times 10^{7}$ promastigotes $/ \mathrm{mL}$ of $L$. infantum were incubated in Schneider's insect medium supplemented with 20\% HIFCS at $26^{\circ} \mathrm{C}$ with concentrations of pterocarpanquinones $2 \mathrm{a}-\mathrm{f}$ ranging from 0 to $5 \mu \mathrm{M}$ in the presence of $20 \mu \mathrm{M} \mathrm{H}_{2}$ DCFDA (Molecular Probes, Eugene, OR, USA). The fluorescence was monitored at $1 \mathrm{~h}$ intervals for $4 \mathrm{~h}$ using 485 and $530 \mathrm{~nm}$ as excitation and emission wavelengths, respectively, using the spectrofluorometer Spectra Max Gemini XPS (Molecular Devices, Silicon Valley, CA, USA). Antimycin A $10 \mu \mathrm{M}$ was used as positive control.

\section{Mitochondrial membrane potential $\left(\Delta \Psi_{m}\right)$ test}

To determine the effect of pterocarpanquinones $2 \mathrm{a}-\mathrm{f}$ on the $\Delta \Psi \mathrm{m}$, promastigotes of $L$. infantum $\left(5 \times 10^{6}\right.$ cells $\left./ \mathrm{mL}\right)$ were incubated in the presence of $0-5 \mu \mathrm{M}$ of derivatives at $26^{\circ} \mathrm{C}$. After $4 \mathrm{~h}$, the parasites were incubated for $15 \mathrm{~min}$ with $10 \mu \mathrm{g} / \mathrm{mL}$ rhodamine 123 (Rh123) (Sigma-Aldrich). Data acquisition of 10,000 events and analysis were performed using the flow cytometer FACSCalibur (Becton-Dickinson, Rutherford, NJ, USA). Alteration in $\Delta \Psi \mathrm{m}$ was quantified using an index of variation (IV) obtained by the eq. IV $=(\mathrm{MT}-\mathrm{MC}) / \mathrm{MC}$ [24], where $\mathrm{MT}$ is the median of the fluorescence of Rh123 for treated parasites and MC is the median of the fluorescence of the control parasites. Negative IV values correspond to depolarization of the
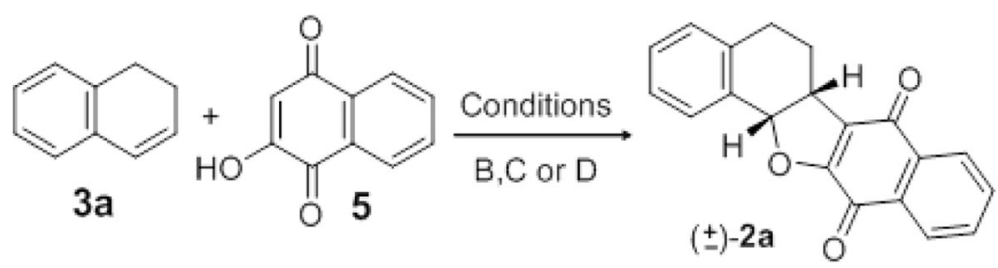

Scheme 2 Dehydrogenative Heck reaction experiments of 3a with 5 
Table 2 Yields of dehydrogenative Heck Reaction experiments

\begin{tabular}{lllll}
\hline Entry & Cond. $^{\text {a }}$ & Time & Oxidant & 2a (\%) \\
\hline 1 & $\mathrm{~B}$ & $18 \mathrm{~h}$ & & $34 \%$ \\
2 & $\mathrm{C}$ & $2.5 \mathrm{~h}$ & & Traces \\
3 & $\mathrm{D}$ & $18 \mathrm{~h}$ & $\mathrm{Cu}(\mathrm{AcO})_{2}$ & $30 \%$ \\
4 & $\mathrm{D}$ & $40 \mathrm{~min}$ & $\mathrm{~K}_{2} \mathrm{~S}_{2} \mathrm{O}_{8}$ & $15 \%$ \\
\hline
\end{tabular}

${ }^{a}$ Conditions: $\mathrm{B}-\mathrm{Pd}(\mathrm{OAc})_{2}(10 \mathrm{~mol} \%), \mathrm{Ag}_{2} \mathrm{CO}_{3}$ (1.5 equiv.), pinacolone, reflux, $\mathrm{C}$ - $\mathrm{Pd}(\mathrm{OAc})_{2}(10 \mathrm{~mol} \%), \mathrm{Ag}_{2} \mathrm{CO}_{3}$ (1.1 equiv.), PEG-400, $140^{\circ} \mathrm{C}$. Conditions: D $\mathrm{Pd}(\mathrm{OAc})_{2}(10 \mathrm{~mol} \%), \mathrm{Ag}_{2} \mathrm{CO}_{3}$ (1.5 equiv.), Oxidant, pinacolone, reflux

${ }^{\mathrm{b}} 2 \mathrm{a}^{\prime}$ was formed in $60: 40$ proportion 2a:2a', respectively

mitochondrial membrane. The FCCP (Carbonyl cyanide- $p$-Trifluoromethoxyphenylhydrazone) $20 \mu \mathrm{M}$ was used as positive control [25].

\section{Statistical analysis}

Antipromastigote and macrophage toxicity assays were repeated three times in triplicate. Antiamastigote assays were repeated three times in duplicate. The results reported for these assays are presented by the Mean \pm SEM. Measurements of ROS and $\Delta \Psi \mathrm{m}$ were performed in triplicate three times. The ROS and index of variation data of the $\Psi \mathrm{m}$ are represented as Mean \pm SD. Significant differences between pairs of groups were assessed using Student's t-test with the significance level set at $p<0.05$. Dose-response significance was evaluated by one-way ANOVA test.

\section{Results}

\section{Chemistry}

Pterocarpanquinones 2a-f were prepared through a palladium-catalyzed oxyarylation of dihydronaphtalen (3a,e, and f) and chromens 3b-d with 3-iodolawsone (4), easily prepared by iodination of lawsone under three reaction conditions (A, B, C, and D). Herein, we used the oxyarylation to obtain type 2 compounds. We first studied the reaction between $3 \mathrm{a}$ and 4 that leads to pterocarpanquinone $2 \mathrm{a}$ (Scheme 1, Table 1). Using acetone as solvent under thermal conditions (Condition A, Table 1, entry 1) 2a was obtained in $20 \%$ after $18 \mathrm{~h}$ of reaction. The reaction was faster under microwave heating ( $40 \mathrm{~min}$.), producing $2 \mathrm{a}$ at a $31 \%$ yield (Table 1, entry 2). Following the classic experimental conditions for a cationic pathway in palladium-catalyzed oxyarylation [26, 27], when 3 equiv. of $\mathrm{Ag}_{2} \mathrm{CO}_{3}$ was used,
Table 3 Yields and conditions for 2b-d

\begin{tabular}{llll}
\hline Entry & Cond. ${ }^{a}$ & 3 & $2(\%)$ \\
\hline 1 & $\mathrm{~B}^{\mathrm{b}}$ & $3 \mathrm{~b} \mathrm{R} \mathrm{R}^{1}=\mathrm{R}^{2}=\mathrm{H}$ & $2 \mathrm{~b}(30 \%)$ \\
2 & $\mathrm{C}$ & $3 \mathrm{~b} \mathrm{R} \mathrm{R}^{1}=\mathrm{R}^{2}=\mathrm{H}$ & $2 \mathrm{~d}(26 \%)$ \\
3 & $\mathrm{~B}$ & $3 \mathrm{c} \mathrm{R}=\mathrm{Cl} ; \mathrm{R}^{2}=\mathrm{H}$ & $2 \mathrm{c}(25 \%)$ \\
4 & $\mathrm{C}$ & $3 \mathrm{c} \mathrm{R}^{1}=\mathrm{Cl} ; \mathrm{R}^{2}=\mathrm{H}$ & $2 \mathrm{c}(72 \%)$ \\
5 & $\mathrm{C}$ & $3 \mathrm{~d} \mathrm{R}^{1}=\mathrm{R}^{2}=-\mathrm{OCH}_{2} \mathrm{O}-$ & $2 \mathrm{~d}(40 \%)$
\end{tabular}

${ }^{a}$ Conditions: $\mathrm{B}-\mathrm{Pd}(\mathrm{OAc})_{2}(10 \mathrm{~mol} \%), \mathrm{Ag}_{2} \mathrm{CO}_{3}$ (1.5 equiv.), pinacolone, reflux, $18 \mathrm{~h} ; \mathrm{C}-\mathrm{Pd}(\mathrm{OAc})_{2}(10 \mathrm{~mol} \%), \mathrm{Ag}_{2} \mathrm{CO}_{3}$ (1.1 equiv.), $\mathrm{PEG}-400,140^{\circ} \mathrm{C}, 10 \mathrm{~min}$ ${ }^{\mathrm{b}} \mathrm{MW}: 40 \mathrm{~W}, 60^{\circ} \mathrm{C}, 110^{\circ} \mathrm{C}, 40 \mathrm{~min}$

did not improve $2 \mathrm{a}$ yields. Therefore, we decided to run the others experiments using 1.5 times the previous salt amount. The yield additionally increased when pinacolone (bp $110^{\circ} \mathrm{C}$ ) was used as the solvent instead of acetone. Under conventional heating, a $57 \%$ yield was obtained from $2 \mathrm{a}$ after $18 \mathrm{~h}$ of reaction (entry 5) while under microwave irradiation $2 \mathrm{a}$ was isolated at $50 \%$ yield after $40 \mathrm{~min}$ of reaction. When PEG-400 was utilized as solvent at $140{ }^{\circ} \mathrm{C}$, 3a reacts with 4 and 2 a could be isolated at a $65 \%$ yield after $10 \mathrm{~min}$. of reaction (Table 1, entry 5), which meant a yield increase when compared with acetone or pinacolone under reflux, using a microwave or not, in little time.

In fact, pterocarpanquinone $2 \mathrm{a}$ could also be obtained by this unprecedented oxyarylation of $3 a$ with lawsone 5 (Scheme 2). Under thermal conditions, 2a was obtained at $34 \%$ yield (entry 1, Table 2). When PEG-400 is used, in $40 \mathrm{~min}$ much degradation of materials was observed and 2a was formed in traces (entry 2, Table 2).

In addition to $2 \mathrm{a}$, we could have isolated and identified by ${ }^{1} \mathrm{H}$ NMR and through $2 \mathrm{D}$ NMR techniques the regioisomer 2a, which did not appear in previous experiments (Scheme 3). The pterocarpanquinones $2 \mathrm{e}$ and $\mathrm{f}$ were obtained at respective yields of 47 and $46 \%$ using PEG-400 as solvent at a lower temperature $\left(90^{\circ} \mathrm{C}\right.$, Table 1 , entries 6 and 7 , Condition D). This type of palladium-catalyzed reaction, also called the dehydrogenative Heck reaction, is in general improved in the presence of an oxidant, to transform $\mathrm{Pd}[0]$ generated at the end of the catalytic cycle to $\mathrm{Pd}[2+]$; but unfortunately in our case, the use of $\mathrm{Cu}(\mathrm{OAc})^{2}$ and $\mathrm{K}_{2} \mathrm{~S}_{2} \mathrm{O}_{8}$ (entries 3 and 4, Table 2) did not lead to better chemical yields. Once better yields were obtained from the oxyaryation using 4 instead of 5 , this compound was used in the
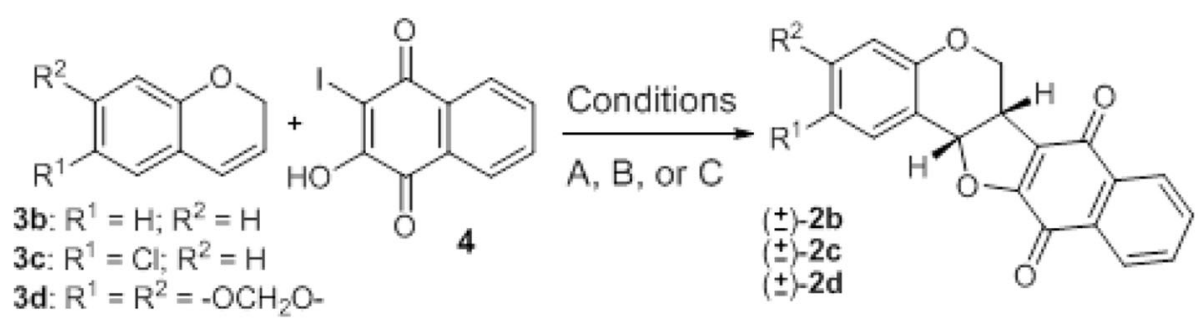

Scheme 3 Synthesis of pterocarpanquinones 2b-d 
Table 4 The action spectrum of second-generation pterocarpanquinones on Leishmania and toxicity in macrophages

\begin{tabular}{|c|c|c|c|c|c|c|c|c|c|c|}
\hline \multirow[t]{3}{*}{ Compounds } & \multirow{3}{*}{$\begin{array}{l}\text { Murine } \\
\text { Macrophage } \\
\mathrm{CC}_{50}(\mu \mathrm{M})\end{array}$} & \multicolumn{3}{|l|}{ L. amazonensis } & \multicolumn{3}{|l|}{ L. braziliensis } & \multicolumn{3}{|l|}{ L. infantum } \\
\hline & & Promastigote & Amastigote & $\left.S\right|^{d}$ & Promastigote & Amastigote & $S I^{d}$ & Promastigote & Amastigote & $S I^{d}$ \\
\hline & & \multicolumn{3}{|l|}{$\mathrm{IC}_{50}(\mu \mathrm{M})$} & \multicolumn{3}{|l|}{$\mathrm{IC}_{50}(\mu \mathrm{M})$} & \multicolumn{3}{|l|}{$\mathrm{IC}_{50}(\mu \mathrm{M})$} \\
\hline LQB 187 (2a) & $49.30 \pm 1.10$ & $1.05 \pm 0.21$ & $0.90 \pm 0.10$ & 54.7 & $23.10 \pm 1.63$ & $9.85 \pm 1.37$ & 5.0 & $1.20 \pm 0.20$ & $>25$ & ND \\
\hline LQB 182 (2b) & $16.90 \pm 1.20$ & $1.08 \pm 0.20$ & $0.85 \pm 0.02$ & 19.8 & $10.98 \pm 1.25$ & $7.84 \pm 2.46$ & 2.15 & $1.00 \pm 0.30$ & $3.60 \pm 0.90$ & 4.69 \\
\hline LQB 236 (2c) & $43.90 \pm 0.60$ & $1.15 \pm 0.18$ & $0.60 \pm 0.13$ & 73.16 & $17.85 \pm 1.12$ & $8.34 \pm 1.47$ & 5.26 & $1.80 \pm 0.30$ & $>25$ & ND \\
\hline LQB 168 (2d) & $77.70 \pm 1.10$ & $1.37 \pm 0.04$ & $0.45 \pm 0.06$ & 172.6 & $28.21 \pm 1.61$ & $7.04 \pm 2.29$ & 11.03 & $2.00 \pm 0.40$ & $>50$ & ND \\
\hline LQB 474 (2e) & $14.92 \pm 1.43$ & $0.50 \pm 0.07$ & $2.60 \pm 0.8$ & 5.74 & $12.34 \pm 0.45$ & $8.53 \pm 1.12$ & 1.74 & $2.20 \pm 0.30$ & $>10$ & ND \\
\hline LQB 475 (2f) & $49.90 \pm .1 .00$ & $0.40 \pm 0.06$ & $2.10 \pm 0.4$ & 23.76 & $10.50 \pm 1.01$ & $9.02 \pm 1.64$ & 5.53 & $1.40 \pm 0.70$ & $>40$ & ND \\
\hline LQB-118 (1) & $18.46^{\mathrm{a}}$ & $1.73^{\mathrm{a}}$ & $1.45^{\mathrm{a}}$ & 12.73 & $3.40^{b}$ & $7.50^{b}$ & 2.46 & $4.08^{c}$ & $3.25^{c}$ & 5.68 \\
\hline Pentamidine & $8.50 \pm 1.25$ & $4.80 \pm 0.09$ & $1.90 \pm 0.10$ & 4.47 & $13.0 \pm 0.04$ & $7.70 \pm 2.40$ & 1.1 & $5.70 \pm 0.12$ & $0.40 \pm 0.20$ & 21.25 \\
\hline
\end{tabular}

ND Not Determined

${ }^{\mathrm{a}}$ reference [14]

b reference [13] e

c reference [12]

${ }^{\mathrm{d}}$ Selective Index $(\mathrm{SI})=\mathrm{CC}_{50}$ in Macrophages $/ \mathrm{IC}_{50}$ in intracellular amastigotes

next experiments. The oxyarylation of chromens $3 b-d$ with 4 (Scheme 3) led to pterocarpanquinones $2 \mathrm{~b}-\mathrm{d}$. Two reaction conditions were used, B (acetone) and C (PEG-400). Compound $2 \mathrm{~b}$ was prepared at $30 \%$ using Condition B while in Condition C, the yield slightly decreases to $26 \%$ yield (entries 1 and 2). For chromens 3c, the yield increased from 25 to $75 \%$ when going from conditions $\mathrm{B}$ to $\mathrm{C}$ (entries 3 and 4). Finally, Compound 2c was formed by oxyarylation of 4 with $3 \mathrm{~d}$, at a moderate yield (40\%) (entry 5) under Condition C (Table 3).

\section{Antipromastigote activity}

$L$. amazonensis, $L$. braziliensis, and $L$. infantum promastigotes were incubated with different concentrations of the pterocarpanquinones for $72 \mathrm{~h}$ and the viability was evaluated. The potency of the derivatives in inhibiting the proliferation of $L$. amazonensis and $L$. infantum promastigotes was similar; nevertheless, $L$. braziliensis had less susceptibility to the pterocarpanquinones. Compared with LQB-118, the compounds $2 \mathrm{a}-\mathrm{f}$ were more potent against $L$. amazonensis and $L$. infantum; however, they presented lower potency against $L$. braziliensis (Table 4 ).

\section{Antiamastigote activity and selectivity}

To evaluate the activity of derivatives against intracellular amastigotes, which correspond to the clinically relevant form of the parasite, peritoneal macrophages were infected with three species of Leishmania and incubated for $72 \mathrm{~h}$ with different concentrations of the pterocarpanquinones. The compound 2d (methylenedioxy group in ring D) showed the lowest $\mathrm{IC}_{50}(0.45 \mu \mathrm{M}$ for $L$. amazonensis; $7.04 \mu \mathrm{M}$ for $L$. braziliensis) for the species causing tegumentary leishmaniasis, which is in relation to second generation derivatives and LQB-118. In addition to improved potency,

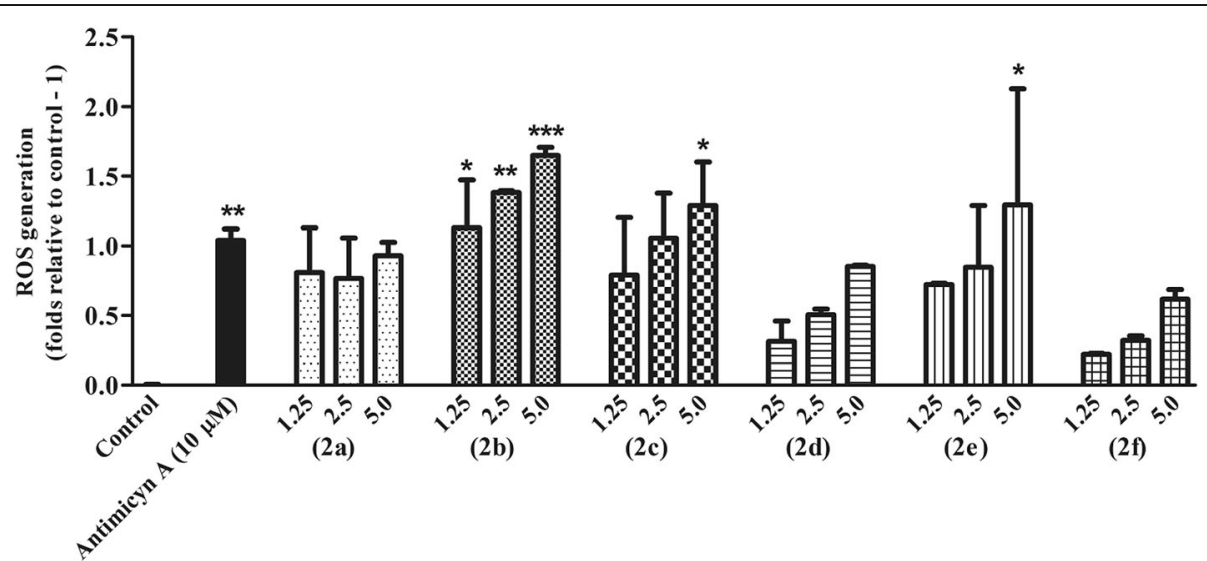

Fig. 2 Early ROS production in L. infantum promastigotes treated with pterocarpanquinones. Promastigotes at $1 \times 107$ cells $/ \mathrm{mL}$ were incubated with 1.25 and $2.5 \mu \mathrm{M}$ of pterocarpanquinones; ROS production was monitored for $4 \mathrm{~h}$ with $20 \mu \mathrm{M}$ of the H2FDCDA, with excitation at $485 \mathrm{~nm}$ and emission at $530 \mathrm{~nm}$. The graph represents the moment $4 \mathrm{~h}$ after incubation. ${ }^{*} p<0.05,{ }^{* *} p<0.01$ and ${ }^{* * *} p<0.001$ compared with control 
derivative 2d showed less toxicity to peritoneal macrophages, with a 4.2-fold lower cytotoxic concentration than LQB-118 $\left(\mathrm{CC}_{50}=77.7 \mu \mathrm{M}\right.$ and $\left.\mathrm{CC}_{50}=18.46 \mu \mathrm{M}\right)$. This decrease in cytotoxicity aligned with increased potency of pterocarpquinone $\mathbf{2 d}$ resulted in a selectivity index of 172.6 for $L$. amazonensis. Despite the potency in intracellular amastigotes of $L$. amazonensis, compound $\mathbf{2 d}$ showed no significant activity in L. infantum amastigote. Only derivative $\mathbf{2 b}$ displayed activity against the three species despite the low selectivity index for L. braziliensis and L. infantum, as presented by the reference drug pentamidine, which showed low index selectivity for L. amazonensis and L. braziliensis, and 10-fold greater selectivity (Table 4).

Pterocarpanquinones induce oxidative stress in $L$. infantum promastigotes

Early Reactive Species Oxygen (ROS) production in promastigotes of $L$. infantum treated with second-generation pterocarpanquinones $(1.25-5.0 \mu \mathrm{M})$ was evaluated with the probe $\mathrm{H}_{2}$ DCFDA for $4 \mathrm{~h}$. The production of ROS after $4 \mathrm{~h}$ of treatment was significant for compounds $2 \mathbf{b}, \mathbf{2 c}$, and $2 \mathbf{e}$ (Fig. 2). The pterocarpanquinone $\mathbf{2 b}$ increased ROS generation dependent on compound concentration, whereas compounds $\mathbf{2 c}$ and $2 \mathbf{e}$ only increased ROS production when the parasite was incubated with the highest concentration of $5 \mu \mathrm{M}$. These results indicate that the presence of pyran and the absence of clusters in ring $\mathrm{D}$ in $R_{1}$ or $R_{2}$ may influence the induction of ROS production.

\section{L. infantum promastigotes altered mitochondrial membrane potential after treatment with pterocarpanquinones}

Promastigotes treated with second-generation pterocarpanquinones for $4 \mathrm{~h}$ had their mitochondrial membrane potential $(\Delta \Psi \mathrm{m})$ evaluated with rhodamine 123 by flow cytometry. The displacement of populations of treated
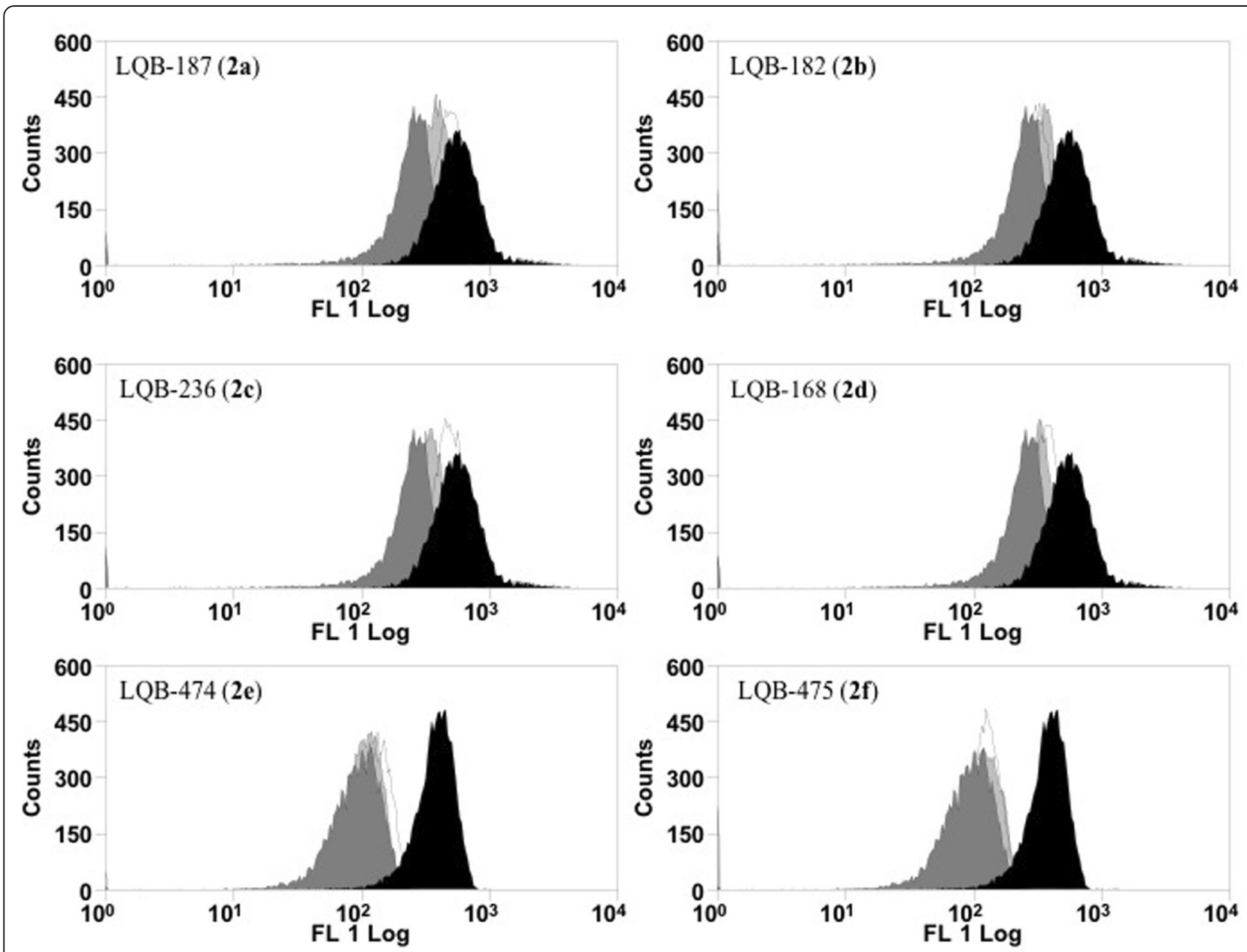

Fig. $3 \mathrm{~L}$. infantum promastigotes altered mitochondrial membrane potential after treatment with pterocarpanquinones. Promastigotes of L. infantum $(5 \times 106$ cells $/ \mathrm{mL})$ were cultured in the presence of $0-2.5 \mu \mathrm{M}$ of derivatives at $26^{\circ} \mathrm{C}$. After $4 \mathrm{~h}$, the parasites were incubated for $15 \mathrm{~min}$ with $10 \mu \mathrm{g} / \mathrm{mL}$ rhodamine 123 (Rh123). Data acquisition and analysis were performed using a FACSCalibur flow cytometer. The FCCP $20 \mu \mathrm{M}$ was used as positive control. Black (control); White $(1.25 \mu \mathrm{M})$; Light Gray $(2.5 \mu \mathrm{M})$ and Dark Gray (FCCP) 
cells, to the left in the histogram, represents the depolarization of the cells, as verified with the positive control used (FCCP), a classical uncoupler of $\Delta \Psi \mathrm{m}$ (Fig. 3). All pterocarpquinones altered the $\Delta \Psi \mathrm{m}$; however, by analysis of the variation index in Table 5, compounds $2 \mathbf{e}$ and $2 \mathbf{f}$ induced greater depolarization in $L$. infantum promastigotes.

\section{Discussion}

Limited therapeutic options in leishmaniasis make its treatment very challenging. This small arsenal has resulted in long-term treatment and severe adverse effects. It is still important to emphasize that there are no vaccines or chemoprophylaxis currently available for humans [28, 29]. Given the therapeutic scenario for leishmaniasis, which includes a spectrum of diseases caused by more than 20 Leishmania species found in many regions of the world [30], there is a need for new drugs that provide efficacy, safety, low cost, oral bioavailability, and action against resistant strains. In this context, the first-generation pterocarpanquinones were designed based on the molecular hybridization of two pharmacophores, quinone, and pterocarpan (derivatives of isoflavonoids). This series was synthesized through a new palladium-catalyzed oxyarylation (oxa-Heck) reaction of chromenquinone with ortho-iodophenol in a four-step production process [2]. The synthesis of the first- and second-generation pterocarpanquinones is in accordance with the proposal of Katsuno et. al., which establishes some generic hit selection criteria for infectious diseases, namely that the hit compound should ideally be synthesized in up

Table 5 Analysis of $\Delta \psi m$. index of variation (IV) of L. infantum promastigotes treated with LQBS

\begin{tabular}{lll}
\hline Compounds & $\mu M$ & Index of variation $^{a}$ \\
\hline Control & 0 & 0 \\
LQB 187 (2A) & 1.25 & $-0.103 \pm 0.16$ \\
& 2.5 & $-0.368 \pm 0.03$ \\
LQB 182 (2B) & 1.25 & $-0.397 \pm 0.07$ \\
& 2.5 & $-0.402 \pm 0.04$ \\
LQB 236 (2C) & 1.25 & $-0.360 \pm 0.16$ \\
& 2.5 & $-0.258 \pm 0.17$ \\
LQB 168 (2D) & 1.25 & $-0.369 \pm 0.08$ \\
& 2.5 & $-0.194 \pm 0.18$ \\
LQB 474 (2E) & 1.25 & $-0.582 \pm 0.1$ \\
& 2.5 & $-0.701 \pm 0.01$ \\
LQB 475 (2F) & 1.25 & $-0.668 \pm 0.01$ \\
FCCP & 2.5 & $-0.707 \pm 0.01$ \\
\hline
\end{tabular}

Values refer to the mean and standard deviation of three experiments MT median fluorescence of treated parasites, MC median fluorescence of control parasites

a The changes in the fluorescence intensity of rhodamine 123 were quantified from the index of variation obtained by the equation (MT - MC) / MC to five steps with an acceptable yield and acceptable solubility [31]. Recent studies have shown that LQB-118 (the first generation of pterocarpanquinones) is a suitable structure for the development of promising drugs for the oral treatment of leishmaniasis [12]; thus, the second generation was produced and its activity spectrum was tested on two species that cause tegumentary leishmaniasis (L. amazonensis and $L$. braziliensis) and a species that causes visceral leishmaniasis (L. infantum). In this work, we answered two pertinent questions about the structure of the first generation pterocarpanquinones: (i) the configuration of the position of rings $B$ (pyran) and $C$ (furan) of the pterocarpan core and (ii) the presence of oxygen in the $B$ ring. When rings $B$ and $\mathrm{C}$ are inverted (2b in comparison to $\mathbf{1}$ ), we noted an improvement of about 1.6 times in the activity against promastigotes and amastigotes of $L$. amazonensis and 4 times against promastigotes of $L$. infantum. Notwithstanding, the opposite was observed in promastigotes of $L$. braziliensis, which presented a decrease of 3.2 times in the antileishmanial activity with the second generation compound. As to the oxygen in the ring $B$ of the new generation, we observed that the oxygenated compound $\mathbf{2 b}$ is approximately two times more active against promastigotes of $L$. braziliensis than its deoxy derivative 2a. Furthermore, on average, the oxygenated compounds $\mathbf{2 b}, \mathbf{2} \mathbf{c}$ and $\mathbf{2 d}$ were more potent against amastigotes of $L$. amazonensis than the deoxy derivatives $\mathbf{2 a}, \mathbf{2 e}$, and $\mathbf{2} \mathbf{f}$. Another modification that improved the activity was the addition of the methylenedioxy group (2d). This group has demonstrated the ability to potentiate the activity of triazole compounds [32], analogs of camptothecin [33], thiosemicarbazones [34] and secondary metabolites isolated from the stem bark of Rollinia emarginata [35]. We verified this potential in the phenotypic trials on $L$. amazonensis and $L$. braziliensis; however, this effect was not seen in promastigotes of L.infantum. The chlorine atom as the substituent in R2 in 2c increased cytotoxicity when compared to $2 \mathbf{b}$ by 2.6 times; this increased cytotoxicity profile was also observed with the insertion of one or two chlorine atoms in the 4-Phenyl-1,3-thiazol-4-amines series [36]. Croft and cols reported that Leishmania species show a significant variation in their sensitivity to established and experimental drugs [37]. As expected, variation in the susceptibility among species was evident in the clinically relevant form of the parasite, the intracellular amastigote. L. amazonensis was the species most susceptible to novel derivatives, whilst $L$. infantum was resistant to most of them. In fact, the compound $2 \mathrm{~b}$ was the only one active against $L$. infantum amastigotes. The mechanism of induction by pterocarpanquinone LQB-118 of L. amazonensis parasite death involved oxidative stress with hallmarks of apoptosis, similar to cancer-induced death [15]. The second-generation pterocarpanoquinones ( $\mathbf{2 b}$ and $\mathbf{2 c}$ ) that possess the oxygen atom in ring $\mathrm{B}$, showed induction of increased ROS production. However, the pterocarpanquinone (2d) with methylenedioxy 
substituent altered this ROS-increasing ability, as also presented by the pterocarpanquinones with an absence of oxygen in the B (2a, 2e, and 2f). Natural and synthetic quinones may undergo redox cycling and induce oxidative stress with ROS production [24, 38].

\section{Conclusion}

The data presented indicate that the second-generation pterocarpanoquinones are promising scaffolds for the development of new leishmanicidal agents.

\section{Funding}

This study was financed by the Coordenação de Aperfeiçoamento de Pessoal de Nível Superior - Brasil (CAPES, Finance Code 001), by the National Council for Scientific and Technological Development (CNPq) and by the Carlos Chagas Filho Foundation for Research Support of Rio de Janeiro State (FAPERJ). Moreover, this publication was supported by the Coordination for the Improvement of Higher Education Personnel (CAPES) through Programa Editoração CAPES - Edital No. 13/2016, No. do Auxílio 0722/2017, No. do Processo 88881.142062/2017-01 and from the National Council for Scientific and Technological Development (CNPq) Programa Editorial CNPq/CAPES process No. 26/2017, Proc. No. 440954/2017-7.

\section{Availability of data and materials}

Available by request to the corresponding author.

\section{Authors' contributions}

Conceptualization, ECTS, PRRC and AJMS; Data curation, VSF, LCRMF, EFCJ, JCFB and TS; Formal analysis, VSF, LCRMF, TS, CDN and SAGS; Funding acquisition, ECTS and PRRC; Investigation, VSF, LCRMF, EFCJ, JCFB and TS; Methodology; EFCJ, JCFB, CDN and SAGS; Supervision, ECTS and AJMS; Writing - original draft, EFCJ and JCFB; Writing - review \& editing, AJMS, SAGS, PRRC and ECTS. All authors read and approved the final manuscript.

\section{Ethics approval and consent to participate}

The studies were performed in accordance with protocols approved by the Ethics Committee for Animal Use of the Oswaldo Cruz Foundation (LW07/ 2010) and the protocol 044/2009 approved by the Ethics Committee on Animal Use (CEUA) of the Instituto de Biologia Roberto Alcantara Gomes of the Universidade do Estado do Rio de Janeiro-UERJ.

\section{Consent for publication}

Not applicable.

\section{Competing interests}

The authors declare that they have no competing interests.

\section{Publisher's Note}

Springer Nature remains neutral with regard to jurisdictional claims in published maps and institutional affiliations.

\section{Author details}

'Laboratório de Bioquímica de Tripanosomatídeos, Instituto Oswaldo Cruz, FIOCUZ, Av. Brasil, 4365, Pavilhao Leonidas Deane, sala 405A, Manguinhos, Rio de Janeiro, RJ 21040-900, Brazil. Instituto de Pesquisa de Produtos naturais, Universidade Federal do Rio de Janeiro, Rio de Janeiro, RJ, Brazil. ${ }^{3}$ Laboratório de Imunofarmacologia Parasitária, Universidade do Estado do Rio de Janeiro, Rio de Janeiro, RJ, Brazil. ${ }^{4}$ Laboratório de Química, Universidade Federal do Rio de Janeiro, campus Professor Aloísio Teixeira, Macaé, RJ, Brazil.
Received: 3 May 2018 Accepted: 7 November 2018

Published online: 29 November 2018

\section{References}

1. Schmidt TJ, Khalid SA, Romanha AJ, Alves TM, Biavatti MW, Brun R, et al. The potential of secondary metabolites from plants as drugs or leads against protozoan neglected diseases - part II. Curr Med Chem. 2012;19(14):2176-228.

2. Netto CD, da Silva AJM, Salustiano EJS, Bacelar TS, Riça IG, Cavalcante MCM, et al. New pterocarpanquinones: synthesis, antineoplasic activity on cultured human malignant cell lines and TNF-alpha modulation in human PBMC cells. Bioorg Med Chem. 2010;18(4):1610-6.

3. Buarque CD, Militão GCG, Lima DJB, Costa-Lotufo LV, Pessoa C, de Moraes $\mathrm{MO}$, et al. Pterocarpanquinones, aza-pterocarpanquinone and derivatives: synthesis, antineoplasic activity on human malignant cell lines and antileishmanial activity on Leishmania amazonensis. Bioorg Med Chem. 2011;19(22):6885-91

4. Silva AJM, Netto CD, Pacienza-Lima W, Torres-Santos EC, Rossi-Bergmann B, Maurel $\mathrm{S}$, et al. Antitumoral, antileishmanial and antimalarial activity of pentacyclic 1,4-naphthoquinone derivatives. J Braz Chem Soc. 2009;20(1):176-82.

5. Salustiano EJ, Dumas ML, Silva-Santos GG, Netto CD, Costa PRR, Rumjanek VM. In vitro and in vivo antineoplastic and immunological effects of pterocarpanquinone LQB-1 18. Investig New Drugs. 2016;34(5):541-51.

6. Maia RC, Vasconcelos FC, de Sá Bacelar T, Salustiano EJ, da Silva LFR, Pereira DL, et al. LQB-118, a pterocarpanquinone structurally related to lapachol [2hydroxy-3-(3-methyl-2-butenyl)-1,4-naphthoquinone]: a novel class of agent with high apoptotic effect in chronic myeloid leukemia cells. Investig New Drugs. 2011;29(6):1143-55.

7. de Faria FCC, Leal MEB, Bernardo PS, Costa PRR, Maia RC. NFKB pathway and microRNA-9 and -21 are involved in sensitivity to the pterocarpanquinone LQB-118 in different CML cell lines. Anti Cancer Agents Med Chem. 2015; 15(3):345-52.

8. Nestal de Moraes G, Castro CP, Salustiano EJ, Dumas ML, Costas F, Lam EW$\mathrm{F}$, et al. The pterocarpanquinone LQB-118 induces apoptosis in acute myeloid leukemia cells of distinct molecular subtypes and targets FoxO3a and FoxM1 transcription factors. Int J Oncol. 2014;45(5):1949-58.

9. de Sá Bacelar T, da Silva AJ, Costa PRR, Rumjanek VM. The pterocarpanquinone LQB 118 induces apoptosis in tumor cells through the intrinsic pathway and the endoplasmic reticulum stress pathway. AntiCancer Drugs. 2013;24(1):73-83.

10. Martino T, Magalhães FCJ, Justo GA, Coelho MGP, Netto CD, Costa PRR, et al. The pterocarpanquinone LQB-118 inhibits tumor cell proliferation by downregulation of c-Myc and cyclins D1 and B1 mRNA and upregulation of p21 cell cycle inhibitor expression. Bioorg Med Chem. 2014;22(12):3115-22.

11. de Souza Reis FR, de Faria FCC, Castro CP, de Souza PS, da Cunha VF, Bello $\mathrm{RD}$, et al. The therapeutical potential of a novel pterocarpanquinone LQB118 to target inhibitor of apoptosis proteins in acute myeloid leukemia cells. Anti Cancer Agents Med Chem. 2013;13(2):341-51.

12. Cunha-Júnior EF, Martins TM, Canto-Cavalheiro MM, Marques PR, Portari EA, Coelho MGP, et al. Preclinical studies evaluating subacute toxicity and therapeutic efficacy of LQB-118 in experimental visceral Leishmaniasis. Antimicrob Agents Chemother. 2016;60(6):3794-801.

13. Costa L, Pinheiro RO, Dutra PML, Santos RF, Cunha-Júnior EF, Torres-Santos EC, et al. Pterocarpanquinone LQB-118 induces apoptosis in Leishmania (Viannia) braziliensis and controls lesions in infected hamsters. PLoS One. 2014:9(10):e109672.

14. da Cunha-Junior EF, Pacienza-Lima W, Ribeiro GA, Netto CD, CantoCavalheiro MM, da Silva AJM, et al. Effectiveness of the local or oral delivery of the novel naphthopterocarpanquinone LQB-118 against cutaneous leishmaniasis. J Antimicrob Chemother. 2011:66(7):1555-9.

15. Ribeiro GA, Cunha-Júnior EF, Pinheiro RO, da-Silva SAG, Canto-Cavalheiro MM, da AJM S, et al. LQB-118, an orally active pterocarpanquinone, induces selective oxidative stress and apoptosis in Leishmania amazonensis. J Antimicrob Chemother. 2013;68(4):789-99.

16. [No authors listed]. Global leishmaniasis update, 2006-2015: a turning point in leishmaniasis surveillance. Wkly Epidemiol Rec 2017;92(38):557-565.

17. Kevric I, Cappel MA, Keeling JH. New world and old world Leishmania infections: a practical review. Dermatol Clin. 2015;33(3):579-93.

18. GBD 2015 DALYs and HALE Collaborators. Global, regional, and national disability-adjusted life-years (DALYS) for 315 diseases and injuries and healthy life expectancy (HALE), 1990-2015: a systematic analysis for the Global Burden of Disease Study 2015. Lancet. 2016;388(10053):1603-58. 
19. Zulfiqar B, Shelper TB, Avery VM. Leishmaniasis drug discovery: recent progress and challenges in assay development. Drug Discov Today. 2017; 22(10):1516-31.

20. Barcellos JCF, Borges BHF, Mendes JA, Ceron MC, Buarque CD, Dias AG, et al. Synthesis of 11a-N-Arylsulfonyl-5-carbapterocarpans (Tetrahydro-5Hbenzo[a]carbazoles) by Azaarylation of Dihydronaphthalenes with o-lodo-N(Arylsulfonyl)anilines in poly(ethylene glycol). Synthesis. 2015;47(19):3013-9.

21. Buarque CD, Domingos JLO, Netto CD, Costa PRR. Palladium-catalyzed Oxyarylation, Azaarylation and a-Arylation reactions in the synthesis of bioactive isoflavonoid analogues. Curr Org Synth. 2015;12(6):772-94.

22. Moraes PF, Gaspar FV, Borges RHF, Netto CD, Leão RAC, Nájera C, et al. Ligand-free palladium-catalyzed Oxyarylation of Dihydronaphthalenes and Chromenequinone with o-lodophenols and 3-lodolawsone in PEG-400: an efficient synthesis of 5-Carbapterocarpans and Pterocarpanquinones. Synthesis. 2015;47(22):3505-12

23. Kulshrestha A, Bhandari V, Mukhopadhyay R, Ramesh V, Sundar S, Maes L, et al. Validation of a simple resazurin-based promastigote assay for the routine monitoring of miltefosine susceptibility in clinical isolates of Leishmania donovani. Parasitol Res. 2013;112(2):825-8.

24. Menna-Barreto RFS, Goncalves RLS, Costa EM, Silva RSF, Pinto AV, Oliveira $M F$, et al. The effects on Trypanosoma cruzi of novel synthetic naphthoquinones are mediated by mitochondrial dysfunction. Free Radic Biol Med. 2009;47(5):644-53.

25. Alexandre TR, Lima ML, Galuppo MK, Mesquita JT, do Nascimento MA, dos Santos AL, et al. Ergosterol isolated from the basidiomycete Pleurotus salmoneostramineus affects Trypanosoma cruzi plasma membrane and mitochondria. J Venom Anim Toxins incl Trop Dis. 2017;23:30. https://doi.org/10.1186/s40409-017-0120-0.

26. Kiss $L$, Antus $S$. A convenient synthesis of pterocarpans. Heterocycl Commun. 2011;6(4):309-14.

27. Kiss L, Papp G, Joó F, Antus S. Efficient synthesis of pterocarpans by heckoxyarylation in ionic liquids. Heterocycl Commun. 2011;7(5):417-20.

28. Sundar S, Singh A. Recent developments and future prospects in the treatment of visceral leishmaniasis. Ther Adv Infect Dis. 2016;3(3-4):98-109.

29. Hefnawy A, Berg M, Dujardin JC, De Muylder G. Exploiting knowledge on Leishmania drug resistance to support the quest for new drugs. Trends Parasitol. 2017:33(3):162-74.

30. Aronson N, Herwaldt BL, Libman M, Pearson R, Lopez-Velez R, Weina P, et al. Diagnosis and treatment of Leishmaniasis: clinical practice guidelines by the infectious diseases society of America (IDSA) and the American Society of Tropical Medicine and Hygiene (ASTMH). Clin Infect Dis. 2016;63(12):1539-57.

31. Katsuno K, Burrows JN, Duncan K. Hooft van Huijsduijnen R, Kaneko T, Kita $\mathrm{K}$, et al. hit and lead criteria in drug discovery for infectious diseases of the developing world. Nat Rev Drug Discov. 2015;14(11):751-8.

32. Costa EC, Cassamale TB, Carvalho DB, Bosquiroli LSS, Ojeda M, Ximenes TV, et al. Antileishmanial activity and structure-activity relationship of Triazolic compounds derived from the neolignans grandisin, veraguensin, and machilin G. Molecules. 2016;21(6):802. https://doi.org/10.3390/ molecules21060802.

33. Werbovetz KA, Bhattacharjee AK, Brendle JJ, Scovill JP. Analysis of stereoelectronic properties of camptothecin analogues in relation to biological activity. Bioorg Med Chem. 2000;8(7):1741-7.

34. de Melos JLR, Torres-Santos EC, Faiões VS, Del Cistia CN, Sant'Anna CMR Rodrigues-Santos CE, et al. Novel 3,4-methylenedioxyde-6-X-benzaldehydethiosemicarbazones: synthesis and antileishmanial effects against Leishmania amazonensis. Eur J Med Chem. 2015;103:409-17.

35. Singh N, Mishra BB, Bajpai S, Singh RK, Tiwari VK. Natural product based leads to fight against leishmaniasis. Bioorg Med Chem. 2014;22(1):18-45.

36. Rodrigues CA, dos Santos PF, da Costa MOL, Pavani TFA, Xander P, Geraldo MM, et al. 4-Phenyl-1,3-thiazole-2-amines as scaffolds for new antileishmanial agents. J Venom Anim Toxins incl Trop Dis. 2018;24:26. https://doi.org/10.1186/s40409-018-0163-x.

37. Croft SL, Yardley V, Kendrick H. Drug sensitivity of Leishmania species: some unresolved problems. Trans R Soc Trop Med Hyg. 2002;96(Suppl 1):S127-9.

38. Pal C, Bandyopadhyay U. Redox-active antiparasitic drugs. Antioxid Redox Signal. 2012;17(4):555-82.

\section{Ready to submit your research? Choose BMC and benefit from:}

- fast, convenient online submission

- thorough peer review by experienced researchers in your field

- rapid publication on acceptance

- support for research data, including large and complex data types

- gold Open Access which fosters wider collaboration and increased citations

- maximum visibility for your research: over $100 \mathrm{M}$ website views per year

At BMC, research is always in progress.

Learn more biomedcentral.com/submissions 